\title{
Groundwater Quality in the Valley and Ridge and Piedmont and Blue Ridge Carbonate-Rock Aquifers, Eastern United States
}

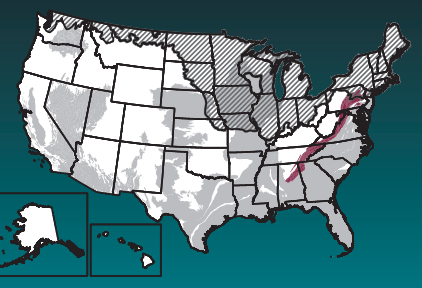

Groundwater provides nearly $\mathbf{5 0}$ percent of the Nation's drinking water. To help protect this vital resource, the U.S. Geological Survey (USGS) National Water-Quality Assessment (NAWQA) Project assesses groundwater quality in aquifers that are important sources of drinking water (Burow and Belitz, 2014). The Valley and Ridge and Piedmont and Blue Ridge carbonaterock aquifers constitute two of the important areas being evaluated.

\section{Background}

The Valley and Ridge (V\&R) carbonate-rock aquifers and the Piedmont and Blue Ridge (P\&BR) carbonate-rock aquifers underlie an area with a population of more than 40 million people in 10 states. The combined V\&R and P\&BR aquifers rank second in the Nation as a source of groundwater for private domestic supply, providing about 470 million gallons per day (Arnold and others, 2016). The V\&R and P\&BR aquifers are also an important source of public supply, providing about 195 million gallons per day. Land use overlying the V\&R and P\&BR aquifers is mostly undeveloped (49 percent), agricultural (35 percent), and urban land (17 percent).

Carbonate rock composing the V\&R and $\mathrm{P} \& \mathrm{BR}$ aquifers dissolves more readily than other rock types (Lindsey and others, 2014). Consequently, valleys in the region tend to be underlain by carbonate aquifers, whereas the adjacent ridges tend to be formed by more resistant rocks such as sandstone. Water-supply wells drilled into carbonate

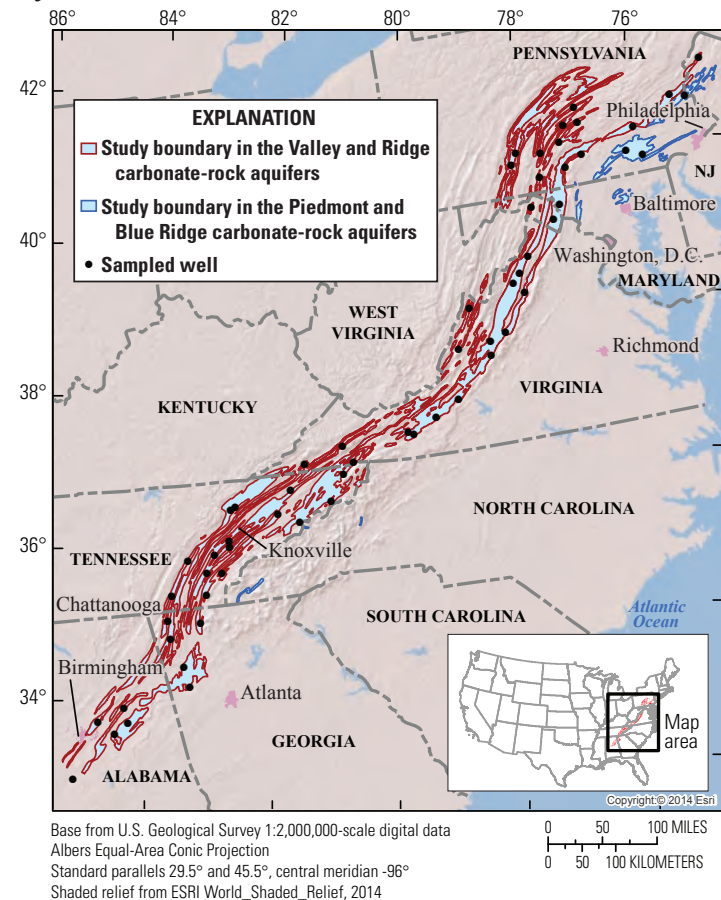
aquifers are generally more productive than wells that tap other rock types. The carbonate aquifers, due to the presence of dissolution channels, are vulnerable to contamination introduced at the land surface. The carbonate aquifers are particularly vulnerable where sinkholes allow for the relatively rapid movement of contaminants into and through the aquifer. In some areas, the carbonate aquifers are locally isolated from the surface by thick layers of clay or shale that can impede the downward movement of water and contaminants.

Groundwater used for public supply is often obtained from a relatively deep zone in the aquifer. In the V\&R and P\&BR carbonaterock aquifers, the top of this zone is typically 50 to 250 feet beneath the land surface, and it is typically 50 to 300 feet thick. Groundwater quality in the V\&R and P\&BR carbonate-rock aquifers was evaluated by sampling 60 spatially distributed public-supply wells in these two aquifers. For this discussion, the study area is defined as the depth zone used for public supply in the V\&R and P\&BR carbonate-rock aquifers. Water-quality data, collected from a set of spatially distributed wells, were used to estimate the percentage of the study area with concentrations that are high, moderate, and low with respect to constituent benchmarks. The accuracy of the estimates depends on the distribution and number of wells, not on the size of the area (Belitz and others, 2010). Samples were analyzed for a large number of water-quality constituents derived from natural and human sources.

\section{Overview of Water Quality}

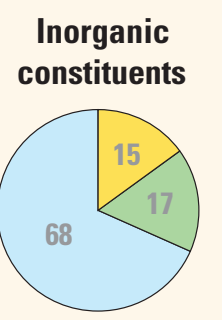

\section{Organic constituents}

\section{CONSTITUENT CONCENTRATIONS}

High $\bigcirc$ Moderate $\bigcirc$ Low or not detected

Values are a percentage of the study area with concentrations in the three specified categories. Percentages might not sum to $\mathbf{1 0 0}$ because of rounding.

Principal Aquifer Studies are designed to evaluate groundwater used for public supply prior to any treatment. Groundwater quality is assessed by comparing concentrations to benchmarks established for drinking-water quality. Benchmarks and definitions of high, moderate, and low concentrations are discussed in the inset box on page 3 .

Many inorganic constituents are naturally present in groundwater. The concentrations of inorganic constituents can be affected by natural processes as well as by human activities. One or more inorganic constituents with human-health benchmarks were detected at high concentrations in about 15 percent of the study area and at moderate concentrations in about 17 percent.

Organic constituents derived from human activities are used in household, business, industrial, and agricultural products. They can enter the environment through normal usage, spills, or improper disposal. Organic constituents were not detected at high concentrations in the study area. One or more organic constituents with human-health benchmarks were detected at moderate concentrations in about 2 percent of the study area. 


\section{Results: Groundwater Quality at the Depth Zone Used for Public Supply in the Valley and Ridge and Piedmont and Blue Ridge Carbonate-Rock Aquifers}

\section{INORGANIC CONSTITUENTS}
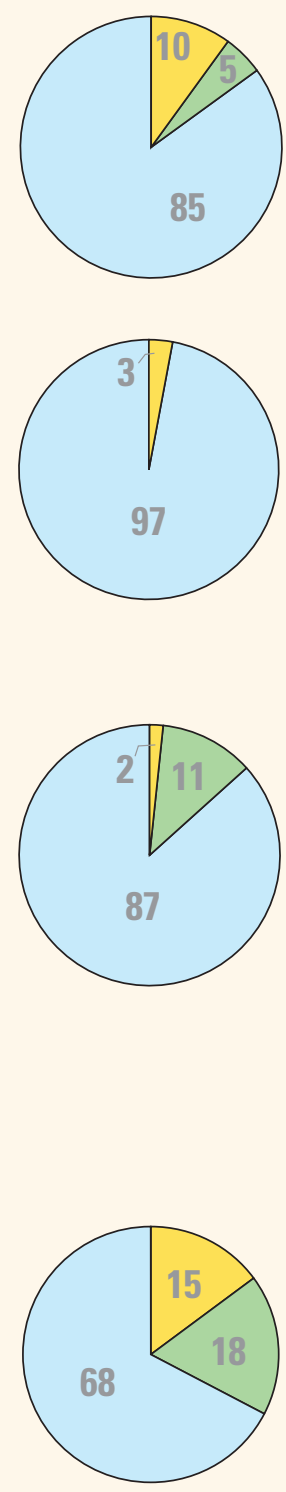

\section{Radioactive \\ constituents}

Nutrients

\section{Trace elements and major and minor ions}

\section{All non-health benchmarks}

\section{Inorganic Constituents with Human-Health Benchmarks}

Trace elements and major and minor ions are naturally present in the minerals of rocks, soils and sediments and in the water that comes into contact with those materials. Samples were analyzed for 34 trace elements and major and minor ions, of which 19 have human-health benchmarks. Constituents from this group were detected at high concentrations in about 10 percent of the study area (the depth zone used for public supply) and at moderate concentrations in about 5 percent. Arsenic, manganese, and strontium were the only trace elements detected at high concentrations.

Radioactivity is the release of energy or energetic particles during spontaneous decay of unstable atoms. Humans are continuously exposed to small amounts of natural radioactivity. Most of the radioactivity in groundwater comes from the decay of isotopes of uranium and thorium that are naturally present in minerals in aquifer materials. Samples were analyzed for eight radioactive constituents, of which four have human-health benchmarks. Radioactive constituents were detected at high levels in about 3 percent of the study area, but were not detected at moderate levels. Gross alpha activity was the only constituent detected at high concentrations.

Nutrients are naturally present at low concentrations in groundwater; high and moderate concentrations (relative to human-health benchmarks) generally result from human activities. Samples were analyzed for five nutrients, of which two have human-health benchmarks. Common sources of nutrients, aside from soils, include fertilizer applied to crops and landscaping, seepage from septic systems, and human and animal waste. Nutrients were detected at high concentrations in about 2 percent of the study area and at moderate concentrations in about 11 percent. Nitrate was the only nutrient detected at high concentrations.

\section{Inorganic Constituents and Field Measurements with Non-Health Benchmarks}

(Not included in water-quality overview charts shown on the front page)

Some constituents affect the aesthetic properties of water, such as taste, color, and odor, or can create nuisance problems, such as staining and scaling. The benchmarks used for these constituents were non-regulatory, secondary maximum contaminant level (SMCL) benchmarks established for public drinking water. Some constituents, such as manganese, have human-health benchmarks and SMCLs. Samples were analyzed for 11 constituents that have SMCLs. One or more of these were present at high concentrations or values relative to the SMCL in about 15 percent of the study area and at moderate concentrations in about 18 percent.

Total dissolved solids (TDS) concentration is a measure of the salinity of the groundwater, and all water naturally contains TDS as a result of the weathering and dissolution of minerals in rocks and sediments. The TDS concentrations can be high because of natural factors or as a result of human activities, such as applications to the land surface of road salt, fertilizers, or other chemicals in urban or agricultural areas. The TDS concentrations were high in about 5 percent of the study area.

Anoxic conditions in groundwater (low amounts of dissolved oxygen) can result in the release of iron and manganese in minerals to the groundwater. Iron and manganese were both present at high concentrations relative to the SMCL in about 5 percent of the study area. Sulfate was present at high concentrations in about 2 percent of the study area.

In a few samples, the $\mathrm{pH}$ of groundwater was not in the SMCL range of 6.5-8.5. In those cases, the $\mathrm{pH}$ was less than 6.5; such waters are considered acidic and potentially corrosive. 


\section{Results: Groundwater Quality at the Depth Zone Used for Public Supply in the Valley and Ridge and Piedmont and Blue Ridge Carbonate-Rock Aquifers}

\section{ORGANIC CONSTITUENTS}

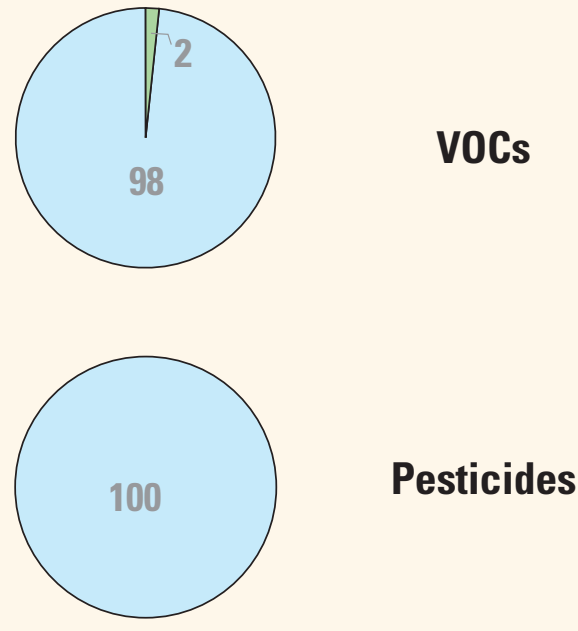

\section{Volatile Organic Compounds with Human-Health Benchmarks}

Volatile organic compounds (VOCs) are present in many household, commercial, industrial, and agricultural products and are characterized by their tendency to volatilize (evaporate). Samples were analyzed for 90 VOCs, of which 38 have human-health benchmarks. No VOCs were detected at high concentrations in the study area; VOCs were detected at moderate concentrations in 2 percent of the study area. The only VOC detected at moderate concentrations was chloroform.

\section{Pesticides with Human-Health Benchmarks}

Pesticides, including herbicides, insecticides, and fumigants, are applied to crops, gardens and lawns, around buildings, and along roads to help control unwanted vegetation (weeds), insects, fungi, and other pests. Samples were analyzed for 227 pesticide compounds (pesticides and their breakdown products), of which 119 have human-health benchmarks. Pesticide compounds were not detected at high or moderate concentrations in the study area.

\section{BENCHMARKS FOR EVALUATING GROUNDWATER QUALITY}

The USGS NAWQA Project uses benchmarks established for drinking water to provide context for evaluating the quality of untreated groundwater. The quality of water received by consumers can be different, because after withdrawal, groundwater may be treated prior to delivery. Federal regulatory benchmarks for protecting human health are used for this evaluation of water quality when available. Otherwise, non-regulatory human-health benchmarks and non-regulatory aesthetic benchmarks are used. Not all constituents analyzed have benchmarks and, thus, are not considered in this context. Out of 55 inorganic constituents and properties and 317 organic constituents, 24 and 157, respectively, have human-health benchmarks.

Concentrations are considered high if they are greater than a human-health benchmark (Toccalino and others, 2014) or SMCL. For inorganic constituents, concentrations are moderate if they are greater than one-half of a benchmark. For organic constituents, concentrations are moderate if they are greater than one-tenth of a benchmark; this lower threshold is used because organic constituents are generally less prevalent and have lower concentrations relative to benchmarks than inorganic constituents (Toccalino and others, 2004).

\section{Benchmark Type and Value for Selected Constituents}

This table presents benchmarks for those constituents detected at high concentrations in the Valley and Ridge and Piedmont and Blue Ridge carbonate-rock aquifers. Benchmark types are regulatory U.S. Environmental Protection Agency maximum contaminant levels (MCLs), non-regulatory health-based screening levels (HBSLs), and non-regulatory secondary maximum contaminant levels (SMCLs).

[Abbreviations: ppb, parts per billion or micrograms per liter $(\mu \mathrm{g} / \mathrm{L})$; ppm, parts per million or milligrams per liter (mg/L); pCi/L, picocuries per liter].

\begin{tabular}{|c|c|c|c|c|c|}
\hline \multirow{2}{*}{ Constituent } & \multicolumn{2}{|c|}{ Benchmark } & \multirow{2}{*}{ Constituent } & \multicolumn{2}{|c|}{ Benchmark } \\
\hline & Type & Value & & Type & Value \\
\hline Arsenic & MCL & $10 \mathrm{ppb}$ & Sulfate & SMCL & $250 \mathrm{ppm}$ \\
\hline Manganese & HBSL & $300 \mathrm{ppb}$ & Manganese & SMCL & $50 \mathrm{ppb}$ \\
\hline Strontium & HBSL & $4,000 \mathrm{ppb}$ & Iron & SMCL & $300 \mathrm{ppb}$ \\
\hline Gross alpha activity & MCL & $15 \mathrm{pCi} / \mathrm{L}$ & Total dissolved solids (TDS) & SMCL & $500 \mathrm{ppm}$ \\
\hline Nitrate as nitrogen & MCL & $10 \mathrm{ppm}$ & $\mathrm{pH}$ & SMCL & $6.5-8.5$ \\
\hline
\end{tabular}




\section{High and Moderate Nitrate Concentrations Found Only in Northern States}

Nitrate concentrations were present at high or moderate concentrations in 13 percent of samples in the depth zone used for public supply; however, the proportions varied from north to south. In the three southernmost States-Alabama (Ala.), Georgia (Ga.), and Tennessee (Tenn.) - no high or moderate concentrations were detected, whereas in the five northernmost States_-Virginia (Va.), West Virginia (W.Va.), Maryland (Md.), Pennsylvania (Pa.), and New Jersey (N.J.) - nitrate concentrations were present at high or moderate concentrations in 23 percent of the study area. The difference in concentrations between the northern and southern parts of these principal aquifers has been previously noted for domestic wells (Johnson and others, 2011) and was attributed to a higher proportion of agricultural activity overlying the aquifers in the northern States.

Arsenic, manganese, gross alpha activity, and strontium were also found at high and moderate concentrations in a small percentage of wells; however, no clear geographic distribution was observed for these constituents. The sources of these chemicals are mostly natural and not related to differences in land use.

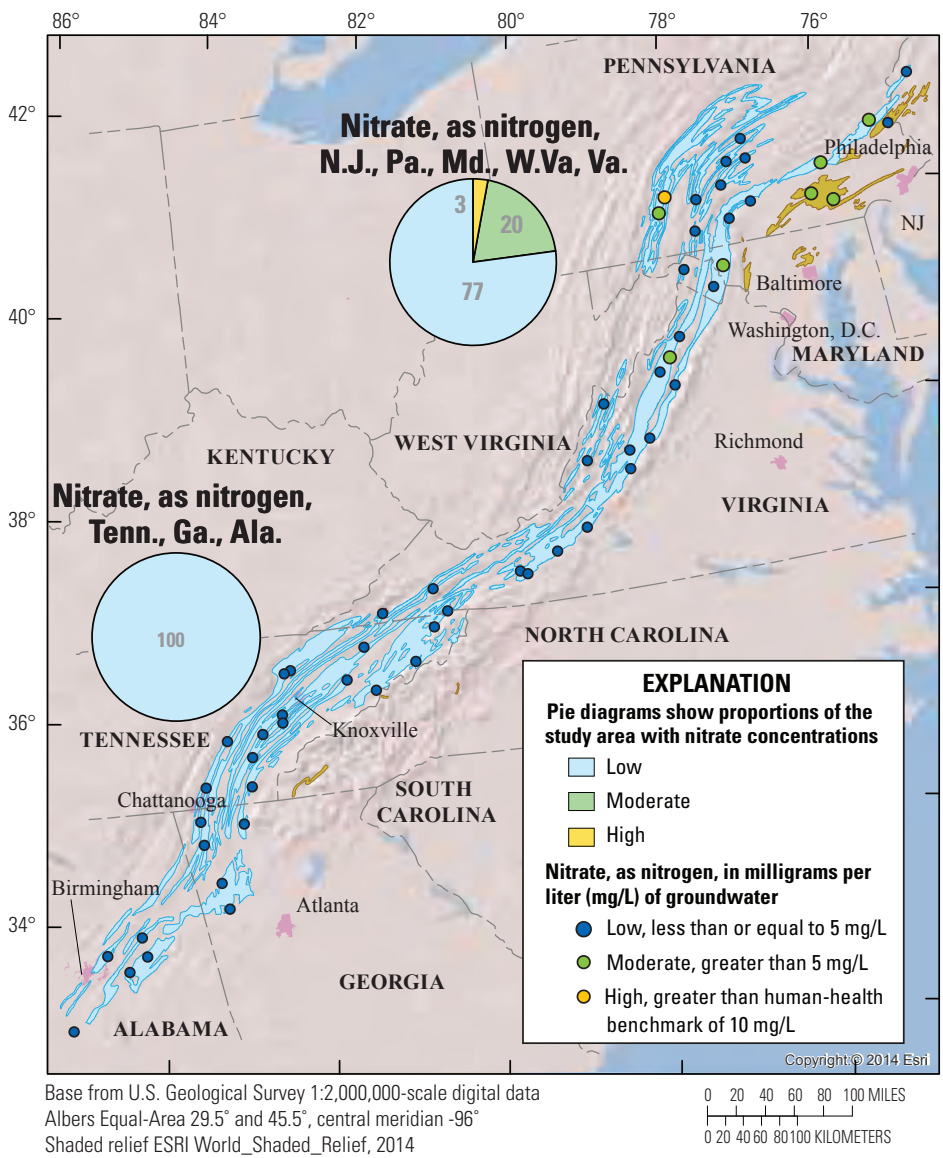

By Bruce Lindsey and Kenneth Belitz

\section{SELECTED REFERENCES}

Arnold, T.L., DeSimone, L.A., Bexfield, L.M., Lindsey, B.D., Barlow, J.R., Kulongoski, J.T., Musgrove, M., Kingsbury, J.A., and Belitz, K., 2016 Groundwater quality data from the National Water-Quality Assessment Program, May 2012 through December 2013: U.S. Geological Survey Data Series Report 997, 56 p., http://dx.doi.org/10.3133/ds997.

Belitz, K., Jurgens B., Landon, M.K., Fram, M.S., and Johnson T., 2010, Estimation of aquifer scale proportion using equal area grids: Assessment of regional scale groundwater quality: Water Resources Research., v. 46, 14 p., http://dx.doi.org/10.1029/2010WR009321.

Burow, K.R., and Belitz, Kenneth, 2014, Groundwater studies—Principal aquifer surveys: U.S. Geological Survey Fact Sheet 2014-3024, 2 p., http://dx.doi.org/10.3133/fs20143024

DeSimone, L.A., McMahon, P.B., and Rosen, M.R., 2014, The quality of our Nation's waters - Water quality in principal aquifers of the United States, 1991-2010: U.S. Geological Survey Circular 1360, 151 p., http://dx.doi.org/10.3133/cir1360.

Johnson, G.C., Zimmerman, T.M., Lindsey, B.D., and Gross, E.L., 2011, Factors affecting groundwater quality in the Valley and Ridge aquifers, eastern United States, 1993-2002: U.S. Geological Survey Scientific Investigations Report 2011-5115, 70 p.

Lindsey, B.D., Zimmerman, T.M., Chapman, M.J., Cravotta, C.A., III, and Szabo, Zoltan, 2014, The quality of our Nation's waters-Water quality in the principal aquifers of the Piedmont, Blue Ridge, and Valley and Ridge regions, eastern United States, 1993-2009: U.S. Geological Survey Circular 1354, 107 p., http://dx.doi.org/10.3133/cir1354.

Toccalino, P.L., Norman, J.E., Phillips, R.H., Kauffman, L.J., Stackelberg, P.E., Nowell, L.H., Krietzman, S.J., and Post, G.B., 2004, Application of health-based screening levels to ground-water quality data in a state-scale pilot effort: U.S. Geological Survey Scientific Investigations Report 2004-5174, 64 p., http://pubs.usgs.gov/sir/2004/5174/.

Toccalino, P.L., Norman, J.E., and Schoephoester, K.M., 2014, Health-based screening levels for evaluating water-quality data, http://water.usgs. gov/nawqa/HBSL, doi:10.5066/F71C1TWP.

\section{Principal Aquifer Studies}

The USGS NAWQA Project has been assessing the quality of groundwater since 1991. The NAWQA studies include Land Use Studies (LUS), Major Aquifer Studies (MAS), and Principal Aquifer Studies (PAS). These three study types are based on sampling networks of wells distributed across an area of interest. The LUS networks typically consist of observation wells that are relatively shallow; MAS networks typically consist of domesticsupply wells that are intermediate in depth; and PAS networks typically consist of public-supply wells that are relatively deep. A national synthesis of shallow and intermediate depth groundwater quality was reported by DeSimone and others (2014), and a regional synthesis of shallow and intermediate depth groundwater quality from the Valley and Ridge (V\&R) and Piedmont and Blue Ridge (P\&BR) carbonate-rock aquifers was reported by Lindsey and others (2014). This fact sheet provides a summary of PAS data for 60 public-supply wells sampled in 2013 in the V\&R and P\&BR carbonate-rock aquifers (data available in Arnold and others, 2016).

The PAS assessments like this one allow for the comparison of constituent concentrations in untreated groundwater with benchmarks established for the protection of human health and for aesthetic qualities of drinking water and also provide a basis for comparison of groundwater quality among the principal aquifers.

The data collected by the NAWQA Project include chemical analyses generally not available as part of regulatory compliance monitoring, including measurements at concentrations much lower than the levels used as humanhealth benchmarks and measurements of constituents that can be used to trace the sources and movement of groundwater.

\section{For more information}

Technical reports and hydrologic data collected for the USGS NAWQA Project may be obtained from:

\section{NAWQA Chief Scientist \\ U.S. Geological Survey \\ 12201 Sunrise Valley Drive, MS 413 \\ Reston, VA 20192-0002 \\ Email: nawqapublicinfo@usgs.gov WEB: http://water.usgs.gov/nawqa/}

